\title{
Molluscicidal Hydroxynaphthoquinones and Derivatives: Correlation Between their Redox Potentials and Activity Against Biomphalaria glabrata
}

\author{
Nadja M. F. Lima ${ }^{a}$, Clariane S. Correia ${ }^{a}$, Patrícia A. L. Ferraz ${ }^{a}$, Antônio V. Pinto ${ }^{b}$, \\ Maria do Carmo R. F. Pinto ${ }^{b}$, Antônio Euzébio G. Santana a and Marília O. F. Goulart ${ }^{*, a}$ \\ ${ }^{a}$ Departamento de Química, CCEN, Universidade Federal de Alagoas, 57072-970 Maceió - AL, Brazil \\ ${ }^{b}$ Núcleo de Pesquisas em Produtos Naturais, Universidade Federal do Rio de Janeiro, 21941-590 \\ Rio de Janeiro - RJ, Brazil
}

\begin{abstract}
Realizaram-se, com algumas 2-hidroxi-3-alquil-1,4-naftoquinonas, bioensaios para verificação de atividade moluscicida contra Biomphalaria glabrata, hospedeiro intermediário do Schistosoma mansoni. Estudos ciclovoltamétricos com algumas dessas mesmas substâncias, em meio aprótico, em N,N-dimetilformamida ou dimetilsulfóxido mais perclorato de tetrabutilamônio, em eletrodos de mercúrio e/ou carbono vítreo, foram, adicionalmente, desenvolvidos, visando à obtenção de informações úteis na elucidação do mecanismo biológico de ação. Várias das quinonas hidroxiladas apresentaram atividades moluscicidas significativas e a correlação entre tais atividades e os parâmetros eletroquímicos medidos, mostrou que o potencial de redução de primeira onda é um parâmetro importante para a atividade biológica. As quinonas mais facilmente redutíveis $\left(>E_{\mathrm{plc}}\right)$ mostraram-se mais ativas frente ao molusco Biomphalaria glabrata, tanto na forma adulta como em massas de ovos, enquanto as 3-metilamino-2-hidroxinaftoquinonas, mais dificilmente redutíveis, não se mostraram ativas como agentes moluscicidas.
\end{abstract}

Several 2-hydroxy-3-alkyl-1,4-naphthoquinones have been submitted to molluscicidal bioassays against the snail Biomphalaria glabrata, intermediate host of Schistosoma mansoni. Cyclic voltammetric studies in aprotic medium (N,N-dimethylformamide plus tetrabutylammonium perchlorate) on $\mathrm{Hg}$ and glassy carbon electrodes have been performed on these compounds in order to obtain information about their biological mechanism of action. Several of the quinones assayed showed significant molluscicidal activities, and correlation of their activities and electrochemical parameters showed that the first wave reduction potential is an important parameter. The easily reduced quinones $\left(>E_{\mathrm{plc}}\right)$ were more active against adult snails and against their egg masses, whilst the 3-methylamino-2-hydroxy derivatives presented higher negative reduction potentials and were not active as molluscicides.

Keywords: hydroxyquinones, molluscicides, Biomphalaria glabrata, redox potential

\section{Introduction}

Schistosomiasis remains a major public health problem in the developing world with an estimated 200 million people infected and 600 million at risk of infection. It is thus important to apply efficient methods to control the transmission of the disease alongside medical treatment for those already infected. Permanent solutions to limit human contact with polluted water and further contamination of the environment ${ }^{1}$ require the provision of safe water and appropriate sanitary facilities, but

* e-mail: mofg@qui.ufal.br sustained progress in the elimination of schistosomiasis cannot be achieved without back up from other approaches, e.g. snail control. ${ }^{2}$ The use of molluscicides in the prophylactic treatment promotes the rupture of the evolutionary cycle of Schistosoma mansoni (the causative agent of schistosomiasis) through the destruction of its intermediate host, the snail Biomphalaria glabrata. ${ }^{3}$ This constitutes the weakest link in the cycle of transmission and is the logic point of attack to control the disease. ${ }^{3}$ New, safe, and effective molluscicides are urgently needed, but in order to be useful the products must be stable, inexpensive, easily applicable and show high selective toxicity to the target pest. ${ }^{4}$ 
Numerous quinones play vital roles in the biochemistry of living cells and exert relevant biological activities. The cytostatic and anti-microbial activities of these quinones emerge by virtue of their ability to act as potent inhibitors of electron transport, as uncouplers of oxidative phosphorylation, as DNA intercalating agents, as bioreductive alkylating agents, and as producers of reactive oxygen radicals by redox cycling under aerobic conditions. In all of these cases the mechanism of action in vivo requires the bioreduction of the quinone as the first activating step. ${ }^{5,6}$ There are other possible mechanisms of action of the quinones, including sulfhydryl arylation, ${ }^{7}$ or topoisomerase involvement, ${ }^{8}$ but these are not based on electron transfer.

Among the biologically active quinones, hydroxynaphthoquinones are important anti-cancer ${ }^{9}$ and anti-protozoal ${ }^{10,11}$ agents: in particular, lapachol (1) and some of its analogues possess anti-tumour, antibiotic, antimalarial, anti-inflammatory and anti-ulcer activities. ${ }^{12}$ Recent results have also demonstrated strong trypanocidal ${ }^{13,14}$ and molluscicidal (against $B$. glabrata) activities $^{14-16}$ for $\mathbf{1}$ and its derivatives and analogues. Lapachol is bioactivated by $\mathrm{P}_{450}$ reductase to reactive species which promote DNA scission through the generation of superoxide anion radicals ${ }^{17}$ by redox cycling. Analysis of the molluscicidal activities of naphthoquinones indicates that simple molecules having an - $\mathrm{OH}$ group in the quinoid ring display low activity, whereas those with a $-\mathrm{CH}_{3}$ group in the quinoid ring possess significant activity. ${ }^{4}$ In the case of alkenyl phenols, the toxicity increases with the number of double bonds in the side chain. ${ }^{4}$

The aim of the present work was to study possible correlations between the electrochemical characters of natural and synthetic 3-substituted-2-hydroxy-1,4naphthoquinones (including isomers and derivatives of lapachol) and their molluscicidal activity with respect to B. glabrata. Redox potentials provide information on the feasibility of electron transfer (ET) in vivo, and established relationships between the ease of reduction (represented by $E_{\mathrm{pc}}, E_{1 / 2}$ or $E_{\text {redox }}$ ) and biological activities demonstrate the relevance of electrochemical studies as tools for the comprehension of drug mechanism of action against various diseases, for the prediction of biological activities, and for the design of potentially active compounds. ${ }^{18,19}$ The environment of the cells could be hydrophilic or lipophilic and, in order to mimic biological conditions, the reduction/oxidation processes can be carried out in non-aqueous media resembling the situation in lipophilic systems or in aqueous media corresponding to situations in most biological fluids. ${ }^{18}$ For studies involving peroxidation processes, non-aqueous aprotic solvents present better models of the membrane environment in which the reactions occur because both the superoxide anion radical and its conjugated acid, the hydroperoxyl radical, are essentially unstable in water and other protic solvents owing to rapid disproportionation. ${ }^{20}$ Additionally, in aqueous medium, hydroxyquinones are greatly influenced by $\mathrm{pH}$, and this would require a complete study of the $\mathrm{pH}$ dependence of the redox potential for every analogue studied.

In the present work, we have studied by cyclic voltammetry (on different electrodes) a collection of twenty four synthetic and natural quinones (Figure 1), all of them oxygenated at $\mathrm{C}_{2}$ but with structural modifications at the oxygenated function ( $\mathrm{OH}, \mathrm{OMe}, \mathrm{OAc}$ or $\left.\mathrm{O}^{-}\right)$. Variations at the $\mathrm{C}_{3}$-alkyl side chain included chain length (5-, 4- and 1 -carbon), the numbers and positions of double bonds (i.e. conjugated as in 2, 3, 7 and 10a-c or isolated as in 1, 6 and 8), and the insertion of a hetero-atom in the form of a substituted $\mathrm{C}_{3}$-methylamine function. In the latter set, secondary $(\mathbf{1 5 - 1 7}, \mathbf{2 0}, \mathbf{2 2})$ and tertiary amines - cyclic (11, $13,14,18)$, aliphatic $(12,19,21)$ - and aromatic $(20,22)$ derivatives were investigated. Along with electrochemical

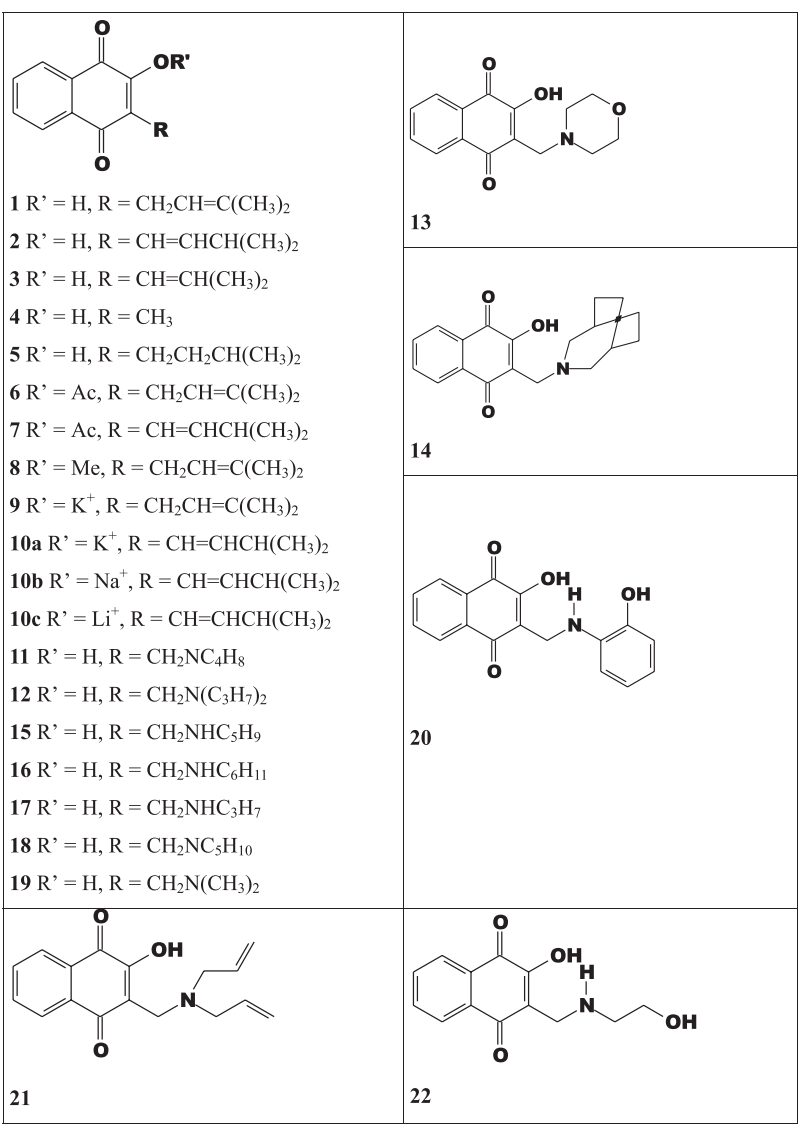

Figure 1. Structures of the analysed compounds. 
studies, biological assays were performed with a view to establishing the possible role of redox potential in the biological mechanism of action.

\section{Experimental}

\section{Chemicals}

All naphthoquinones (Figure 1) used in this work were synthesised using previously reported methods except for compounds $\mathbf{1}$ [which was isolated from natural sources and kindly supplied by Produtos Vegetais do Piauí (PVP, Parnaíba, Piauí, Brazil)] and $\mathbf{4}$ (which was purchased from Aldrich). Compound $\mathbf{2}$ was synthesised as previously described; ${ }^{21}$ 11-22 were synthesised by the Mannich reaction; ${ }^{22} \mathbf{5}$ was obtained in $90 \%$ yield by catalytic hydrogenation in ethanol over $\mathrm{Pd} / \mathrm{C}(10 \%) ; 6$ and 7 were formed by acetylation with acetic anhydride and anhydrous sodium acetate ${ }^{23}$ with yields of 80 and $54 \%$, respectively; 8 was produced in $70 \%$ yield by reaction with diazomethane; the salts 9 and 10a-c were produced as described, ${ }^{23}$ from aqueous saturated solutions of the respective hydroxides, or from equivalent amounts of their respective salts in ethanol, distillation of the solvent and several washings with cold ether to eliminate residues of the initial compounds ${ }^{24}$ in yields of $c a .83 \% .^{23,24}$ All compounds were fully characterized or compared with authentic samples, and all showed analytical and spectral (IR, NMR) data in full accord with the indicated structures.

The solvents DMF and DMSO were previously distilled under reduced pressure, after treatment with copper sulphate and calcium hydride, respectively.

\section{Biological assays}

Molluscicidal assays against $B$. glabrata were carried out using a previously reported method ${ }^{24}$ which was slightly modified by the inclusion of an inert solvent to help with the dissolution of samples. The compounds were first dissolved in a small amount of DMSO which was then diluted with de-chlorinated water to give a solution containing only $0.1 \%$ DMSO.

The bioassay involved the immersion of snails in aqueous DMSO solutions of the compound under investigation at appropriate concentrations for $24 \mathrm{~h}$; snails were then washed, transferred to tanks containing dechlorinated water and observed over $96 \mathrm{~h}$. The criteria used for snail death were inactivity, discoloration and, ultimately, production of a foul odour upon crushing.

For the bioassays involving eggs, masses aged 0-1 day were collected from the sides of the tank containing the snails or from plastic sheets immersed in the tank. For each concentration tested, four egg masses, each containing 1540 embryos, were immersed in the aqueous DMSO solution of the sample for $96 \mathrm{~h}$; after $24 \mathrm{~h}$, and subsequently until the end of the assay, each individual embryo in each egg mass was checked with a binocular microscope. An embryo was considered dead if the cells became opaque or desegregated.

In order to verify the viability of the snails and the embryos employed in the bioassays, two control experiments were performed - one with cupric carbonate at $50 \mathrm{ppm}$ and the other with de-chlorinated water containing $0.1 \%$ DMSO. The collected data were computerised, and the $\mathrm{LD}_{10}$ (not shown), $\mathrm{LD}_{50}$ and $\mathrm{LD}_{90}$ values determined by performing a probit analysis.

\section{Electrochemical assays}

Cyclic voltammetry was performed in DMSO/ tetrabutylammonium perchlorate (TBAP) or DMF/TBAP (0.1 $\left.\mathrm{mol} \mathrm{L}^{-1}\right)$, using $\mathrm{Hg}$ and/or glassy carbon (GC) as the working electrode, and platinum and $\mathrm{Ag} / \mathrm{AgCl}, \mathrm{Cl}^{-}$ (0.1 mol $\left.\mathrm{L}^{-1}\right)$ as counter and reference electrodes, respectively. The scan rate was $0.100 \mathrm{~V} \mathrm{~s}^{-1}$. Test solutions of

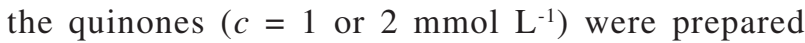
immediately before the electrochemical experiments were conducted, and dissolved oxygen was eliminated by bubbling the solution with dry nitrogen. During the experiments, the cell was kept in a dark Faraday cage to minimize photoreactions and external electric fields. Details of the equipment employed have already been published..$^{25}$

\section{Results and Discussion}

\section{Biological aspects}

In order to become commercially acceptable, molluscicides have to fulfil certain requirements. Their molluscicidal activity can be considered satisfactory if $\mathrm{LD}_{100}$ is close to the activity presented by the strongest synthetic molluscicides, which lies around 1 ppm. ${ }^{4}$ Furthermore, the capacity to kill the eggs of B. glabrata is an essential feature for any molluscicide which is to be considered for use in schistosomiasis control.

In the present work, which employed pure compounds, $\mathrm{LD}_{90}$ values $<10 \mathrm{ppm}$ and $<1$ ppm for adult snails and egg masses, respectively, were indicative of promising active compounds; inactive compounds showed $\mathrm{LD}_{90}$ values $>100$ ppm. Table 1 reports the results of the assays performed against adult snails and egg masses of $B$. glabrata showing the calculated values of $\mathrm{LD}_{50}$ and $\mathrm{LD}_{90}$. 
Table 1. Molluscicidal activities $\left(\mathrm{LD}_{50}\right.$ and $\mathrm{LD}_{90}$ values in $\mathrm{ppm}$ ) of compounds $\mathbf{1} \mathbf{- 2 0}$ against Biomphalaria glabrata (adult and egg masses) and $E \mathrm{p}_{1 \mathrm{c}}(\mathrm{V})$ values on different electrodes

\begin{tabular}{|c|c|c|c|c|c|c|}
\hline \multirow[t]{2}{*}{ Compounds } & \multicolumn{2}{|c|}{$\mathrm{LD}_{50}(\mathrm{ppm})$} & \multicolumn{2}{|c|}{$\mathrm{LD}_{90}(\mathrm{ppm})$} & \multicolumn{2}{|c|}{$\begin{array}{l}-E \mathrm{p}_{\mathrm{Ic}}, \mathrm{DMF} / \mathrm{TBAP} 0.1 \mathrm{~mol} \mathrm{~L}^{-1} \\
\mathrm{~V} \text { vs. } \mathrm{Ag}, \mathrm{AgCl}, \mathrm{Cl}^{-} 0.1 \mathrm{~mol} \mathrm{~L}^{-1}\end{array}$} \\
\hline & Adult & Egg & Adult & Egg & $\mathrm{Hg}$ & GC \\
\hline 1 & 2.57 & 0.055 & 6.18 & 0.190 & 0.715 & 0.666 \\
\hline 2 & 1.53 & 0.034 & 4.30 & 0.092 & 0.438 & 0.642 \\
\hline 3 & 4.02 & 0.014 & 7.15 & 0.070 & 0.708 & ND \\
\hline 4 & 5.19 & 4.08 & 18.46 & 7.385 & 0.713 & ND \\
\hline 5 & 0.98 & 0.278 & 1.98 & 0.600 & 0.720 & 0.670 \\
\hline 6 & 6.91 & ND & 11.55 & ND & 0.660 & $0.599,0.597^{\circ}$ \\
\hline 7 & 1.66 & 0.497 & 3.08 & 0.998 & ND & $0.560,0.552^{\circ}$ \\
\hline 8 & 7.72 & 38.26 & 15.17 & 78.71 & 0.768 & $0.719^{\mathrm{c}}$ \\
\hline $9^{\mathrm{b}}$ & 2.70 & 1.43 & 6.72 & 2.52 & ND & ND \\
\hline $10 a^{b}$ & 3.05 & 0.33 & 4.71 & 0.48 & ND & ND \\
\hline $10 \mathrm{~b}$ & ND & 0.265 & ND & 0.409 & ND & ND \\
\hline $10 \mathrm{c}$ & ND & 0.365 & ND & 0.666 & ND & ND \\
\hline 12 & ND & 16.13 & ND & 45.72 & 0.813 & 0.810 \\
\hline $13^{\mathrm{a}}$ & I & I & I & I & ND & $0.780^{\mathrm{c}}$ \\
\hline 16 & I & I & I & I & ND & 0.870 \\
\hline 19 & 3.82 & 2.67 & 16.67 & 6.54 & ND & 0.805 \\
\hline 20 & 4.62 & & 23.92 & $>5$ & ND & ND \\
\hline
\end{tabular}

${ }^{\mathrm{a}}$ unstable; ${ }^{\mathrm{b}}$ can be protonated with recovery of $\mathbf{1}$ and $\mathbf{2}$, respectively;

${ }^{c}$ DMSO/TBAP $0.1 \mathrm{~mol} \mathrm{~L}^{-1} ; \mathrm{I}=$ inactive; ND = not determined

Compounds 1-3, 5, 7, 9 and 10a presented significant molluscicidal activities against the adult form of the snail, with $\mathrm{LD}_{90}$ values in the range of $1.98-7.15 \mathrm{ppm}$; for the more sensitive embryo forms of B. glabrata the results were similar and quite impressive with $\mathrm{LD}_{90}$ values $<1$ ppm for compounds $\mathbf{1 0 b}$ and 10c. Compounds $\mathbf{2}$ and $\mathbf{3}$ can also be considered significantly active. The $\mathrm{LD}_{50}$ values of all of these compounds (Table 1) are similar or lesser than those presented by various molluscicides ${ }^{26}$ such as muzigadial $\left(\mathrm{LD}_{50}=5\right.$ to $\left.10 \mathrm{ppm}\right)$, warburganal $\left(\mathrm{LD}_{50}=2\right.$ $\mathrm{ppm})$, mukaadial $\left(\mathrm{LD}_{50}=20 \mathrm{ppm}\right)$, despite being higher than those of niclosamide $\left(\mathrm{LD}_{50}=0.06 \mathrm{ppm} ; \mathrm{LD}_{90}=0.10\right.$ $\mathrm{ppm}^{27}$ ). Phytiocol (4) and the quinone derivatives 6 and 8 were reasonably active with compound $\mathbf{8}$ showing a unique reversal of activity in that the compound was less active against egg masses than against the adult snails. The 3methylamino-2-hydroxy derivatives 11, 13-18, 21 and 22 were inactive, whilst 12, 19-20 were only poorly active.

\section{Electrochemical aspects}

The electrochemical behaviour of different classes of quinones has been extensively reviewed..$^{25}$ In the specific case of hydroxyquinones, the possibility of stabilization of the electrogenerated anion radical by intramolecular hydrogen bonding causes a shift of the reduction potentials to less negative values, ${ }^{28,29} \mathrm{a}$ fact that in some cases can be fundamental with respect to biological activity. ${ }^{29}$ For peroxidation in the presence of oxygen to occur, the presence of hydroxyl groups in the quinone moiety has been demonstrated to be essential. ${ }^{20}$

The natural and synthetic hydroxynaphthoquinones (NQOH) tested (Table 1) showed typical voltammograms (Figure 2) on $\mathrm{Hg}$ and $\mathrm{GC}$ electrodes in aprotic medium (DMF + TBAP or DMSO + TBAP). DMF and DMSO, two very similar aprotic solvents, were used owing to the instability of some of the quinones in DMF. The latter solvent, however, has a larger electrochemical domain on the anodic side than does DMSO. Two different types of electrode were also employed: a $\mathrm{Hg}$ electrode was to permit comparison with data available in the literature, whilst experiments with a GC electrode were performed in order to investigate the electro-oxidisable groups. The differences between the data collected using the two protocols are not significant as can be observed by comparison of columns 6 and 7 in Table 1 .

The voltammograms are represented by two main pairs of peaks - the first cathodic peak (labelled Ic) with a related anodic peak (Ia), and the second pair designated IIIc (cathodic) and IIIa (anodic): the associated processes were irreversible and quasi-reversible in nature, respectively. Intermediate shoulders (IIc and IIc) are also present (Figure $2 \mathrm{~A}, \mathrm{~B})$ which showed strong dependence upon the scan rate. ${ }^{25}$ A self-protonation mechanism with hydrogenbonded intermediates explains the nature of the first peaks and shoulders. ${ }^{25}$ The first pair of peaks is related to the semiquinone (NQOH:) and the last pair to the quasireversible two-electronic reduction of the respective anion 

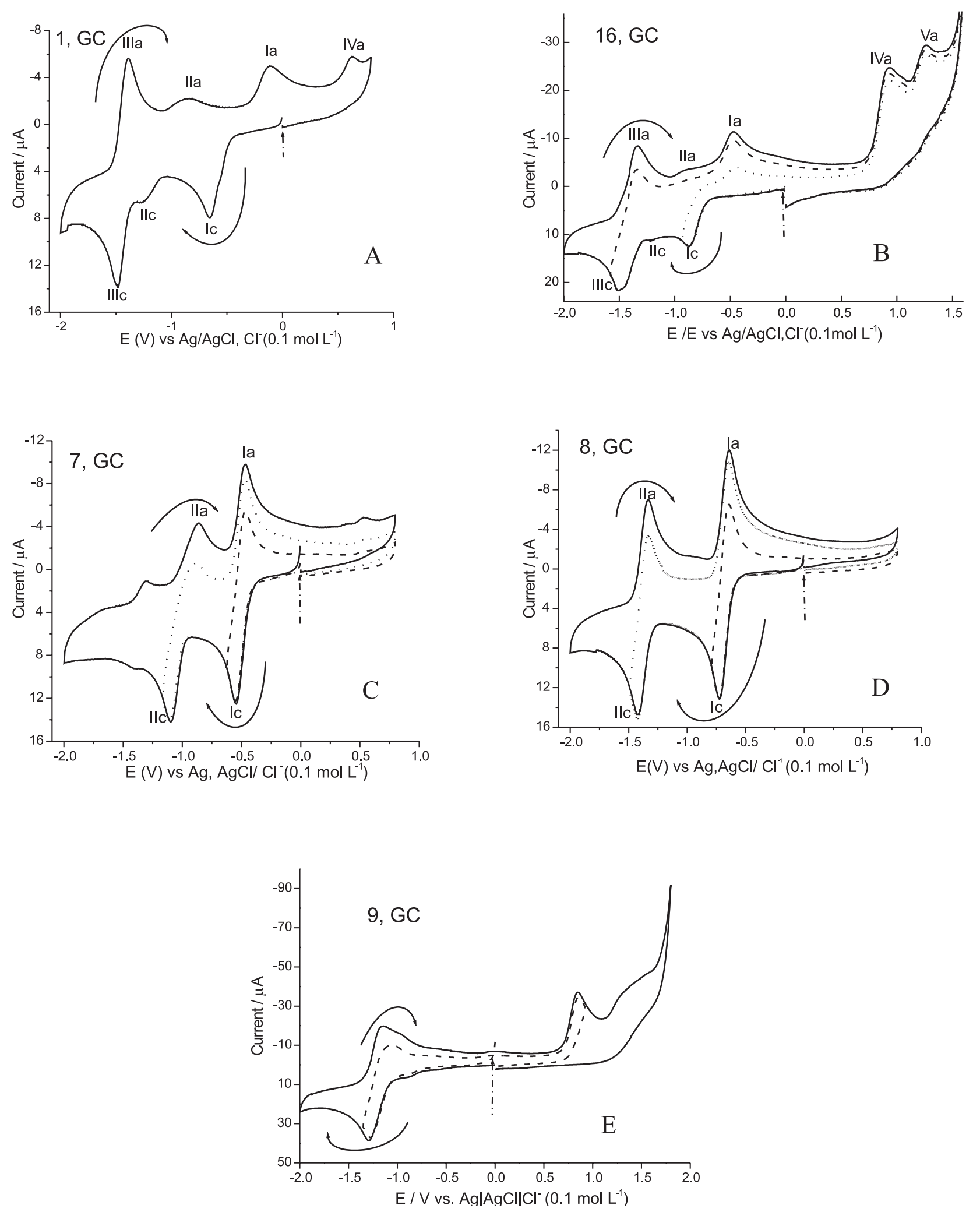

Figure 2. Cyclic voltammograms of the analysed compounds. E vs. $\mathrm{Ag} / \mathrm{AgCl}, \mathrm{Cl}-0.1 \mathrm{~mol} \mathrm{~L}^{-1}$. DMSO/TBAP or DMF/TBAP $0.1 \mathrm{~mol} \mathrm{~L}{ }^{-1}$ (B, E), glassy carbon electrode, $\mathrm{n}=0.100 \mathrm{~V} \mathrm{~s}^{-1}$. 
of the 2-hydroxynaphthoquinones (NQO-). ${ }^{25}$ The amino derivatives (Figure $2 \mathrm{~B}$ ) reduce in a similar way, except on the anodic arm of the voltammogram which showed the presence of additional oxidation waves ${ }^{30}$ related to the oxidation of the amino groups to the respective cationradicals: ${ }^{31}$ these suffer reduction at more negative potentials.

The behaviour of the hydroxylated quinones is totally different from the very characteristic features of the nonhydroxylated quinones represented by two reversible mono-electronic waves generating, after the first and second electron captures, the quinone anion radical and the dianion, respectively, as observed for 6-8 (Figure $2 \mathrm{C}$, D). Comparison of the voltammetric features (Figure $2 \mathrm{~A}$, B vs. C, D) showed the strong influence exerted by the hydroxylic proton: in its absence, simpler voltammograms were obtained with the predictable effect of the substituents, i.e. compounds $\mathbf{6}$ and $\mathbf{7}$ were reduced more readily than $\mathbf{8}$. For the salts (10a-c), the voltammograms showed only one reduction wave at a more negative potential (Figure $2 \mathrm{E}$ ) demonstrating the important role of the acidic enolic proton as expected. In vivo, the enolate should be re-protonated, giving rise to the original hydroxyquinone.

Based on data presented in Table 1, the ease of reduction on $\mathrm{Hg}$, represented by the potential of the first well-defined wave $\left(E_{\mathrm{pIc}}\right)$ at $v=0.100 \mathrm{~V} \mathrm{~s}^{-1}$, follows the order: $\mathbf{2}>\mathbf{3}>\mathbf{6}>$ 4 $\sim \mathbf{5} \sim \mathbf{1}>\mathbf{8}>\mathbf{1 2}$. On GC, a similar order may be observed, namely $7>6>2>1 \sim 5>8>13>19 \sim 12>16$, except that $\mathbf{2}$ is reduced more readily on $\mathrm{Hg}$. The observed reduction potential differences are probably related to the acidic strength of the $\mathrm{OH}$ group and to the electron withdrawing characteristics of the substituents. For the remaining amino derivatives, electroreduction is more difficult ${ }^{30}$ since, despite the marked inductive effect (-I), the amino moiety separated by a methylene spacer acts as an electron donor in the donor-acceptor (D-A) interactions giving rise to the expected behaviour. ${ }^{30}$

\section{Correlation studies}

Concerning structural parameters, for compounds with the same hydrocarbon side chain, molluscicidal activity was highest for $\mathrm{R}^{\prime}=\mathrm{H}$, slightly less for $\mathrm{R}^{\prime}=\mathrm{K}^{+}$or $\mathrm{Li}^{+} \mathrm{Or} \mathrm{Na}^{+}$ and decreased markedly (with the exception of compound 7) when the hydroxyl group was substituted with methyl or acetyl: acetyl derivatives were more active than methoxy ones. It should be emphasised, however, that esters, to a greater extent than ethers, are readily hydrolysed in vivo yielding the original hydroxylated compounds. This might indicate a significant role of the active hydroxyl proton. The activity decreases with the shortening of the hydrocarbon tail and with the introduction of a basic nitrogen on the side chain. All of the amino derivatives were inactive or weakly active $(\mathbf{1 2}, \mathbf{1 9}, \mathbf{2 0})$, with the aromatic amines being the more active in the series. A detailed study of the influence of structure and of pKa on redox potential will be published elsewhere.

Plots of $E_{\mathrm{pIc}}$ values for chosen quinones measured on $\mathrm{Hg}$ and $\mathrm{GC}$ electrodes versus molluscicidal activity (represented by $\mathrm{LD}_{90}$ values) against adult snails and egg masses are shown on Figure 3. The $E_{\mathrm{pIc}}$ values of the salts are not included since, after protonation, they return to the original quinones $\mathbf{1}$ and $\mathbf{2}$. Figure 3 demonstrates that there is not a linear correlation between these data, however, it may be observed that the majority of the active compounds appear in the lower-left quadrant of the plot, whilst the less active and the inactive quinones are present in the opposite quadrant, hence indicating a trend. On the $\mathrm{Hg}$ electrode, a cut-off potential close to $-0.72 \mathrm{~V}$ is evident, while on the GC electrode the value is $>-0.70 \mathrm{~V}$. Exceptions, represented by compounds $\mathbf{4}$ and $\mathbf{6}$, indicate that although $E_{\mathrm{pIc}}$ appears to be related to molluscicidal activity, other factors, such as diffusion, solubility, metabolism, membrane permeability, bioavailability, and partition coefficient must also be considered. Similar results have been observed for the anti-neoplastic furanoquinones where hydroxyl substituted derivatives showing internal hydrogen bonding exhibited the most positive $E_{1 / 2}$ values and were generally more active. ${ }^{28}$ Additionally, more electrophilic quinones $\left(E_{\mathrm{plc}}>-0.72 \mathrm{~V}\right.$ versus $\mathrm{Ag}, \mathrm{AgCl}, \mathrm{Cl}^{-}$) were active in vitro against trypomastigotes of Trypanosoma cruzi, while most of those with $E_{\mathrm{plc}}<-0.72 \mathrm{~V}$ were inactive, suggesting a contribution of the facility of reduction on biological activity. ${ }^{13}$

\section{Conclusions}

Several of the assayed quinones showed significant molluscicidal activities; compounds $\mathbf{5}$ and $\mathbf{3}$ were the most active against adult snail and egg masses, respectively. Comparison between the molluscicidal activities and electrochemical parameters showed that the first wave reduction potential is an important parameter: the readily reduced quinones $\left(>E_{\mathrm{plc}}\right)$ were more active against the adult snails and against their egg masses. The 3-methylamino2-hydroxy derivatives presented more negative reduction potentials and were inactive as molluscicides. The observed trend suggests that bioreduction could play an important role in the molluscicidal activity of these compounds, however, other factors must also be considered.

Electrochemical parameters cannot give an absolute correlation with biological activity data owing to the 

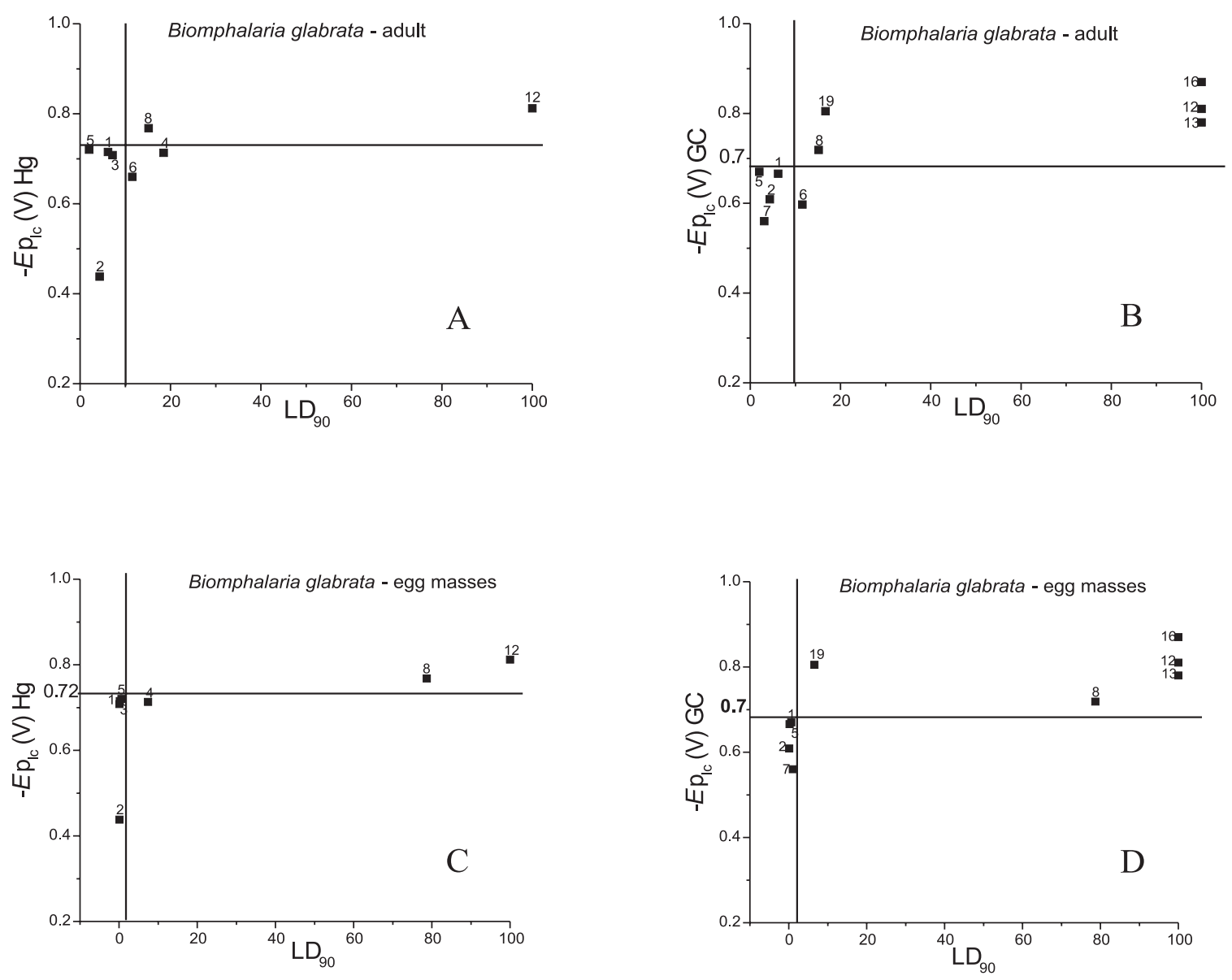

Figure 3. Plots of $E_{\mathrm{plc}}$ on $\mathrm{Hg}(\mathbf{A}, \mathbf{C})$ and $\mathrm{GC}(\mathbf{B}, \mathbf{D})$ electrodes versus molluscicidal activity (represented by $\mathrm{LD}_{90}$ in ppm) against adult snails $(\mathbf{A}$, B) and egg masses $(\mathbf{C}, \mathbf{D})$ of Biomphalaria glabrata.

enormous complexity of the biological chemistry involved. Indeed, in a live host, this kind of relationship is always a complex outcome not usually dominated by a sole parameter. Caution must always be used in interpreting this kind of correlation and many other important factors must be considered in the mechanistic aspects of in vivo drug activity, e.g., stereochemistry, diffusion, solubility, metabolism, membrane permeability etc. Other parameters, such as bioavailability, partition coefficient and specific enzyme interactions, also play critical roles ${ }^{18}$ and studies concerning these aspects are currently under way in our laboratory.

\section{Acknowledgements}

The authors wish to thank CNPq, CAPES and FAPEAL for financial support and fellowships, Luciana A. Silva for technical assistance and Aldenir F. dos Santos for fruitful discussions.

\section{References}

1. Chitsulo, L.; Engels, D.; Montresor, A.; Savioli, L.; Acta Trop. 2000, 77, 41.

2. Yuan, H.; Jiagang, G.; Bergquist, R.; Taner, M.; Xianyi, C.; Huanzeng, W.; Parasitol. Int. 2000, 49, 195.

3. Perrett, S.; Whitfield, P. J.; Parasitol. Today 1996, 12, 156.

4. Singh, O. K.; Misra, T. M.; Agarwal, R. A.; Biol. Agric. Hort. 1996, 13, 205.

5. Monks, T. J.; Hanzlik, P.; Cohen, G. M.; Ross, D.; Graham, D. G.; Toxicol. Appl. Pharmacol. 1992, 112, 2.

6. O’Brien, P. J.; Chem.-Biol. Interact. 1991, 80, 1.

7. Irons, R.D.; Sawahata, T. In Bioactivation of Foreign Compounds; Anders, M. W. ed.; Academic Press: New York, 1985, ch. 9.

8. Frydman, B.; Marton, L.J.; Sun, J.S.; Neder, K.; Witiak, D.T.; Liu, A.A.; Wang, H.; Mao, Y.; Wu, H.; Sanders, M.M.; Liu, L.F.; Cancer Res. 1997, 57, 620.

9. Powis G.; Pharmacol. Ther. 1987, 35, 57. 
10. Croft, S. L.; Hogg, J.; Gutteridge, W. E.; Hudson, A. T.; Randall, A. W.; J. Antimicrob. Chemother. 1992, 30, 827.

11. Munday, R.; Smith, B. L.; Munday, C. M.; Chem.-Bio. Interact. 1995, 98, 185.

12. Subramanian, S.; Ferreira, M.M.C.; Trsic, M.; Struct. Chem. 1998, 9, 47.

13. Goulart, M. O. F.; Zani, C. L.; Tonholo, J.; Freitas, L. R.; de Abreu, F. C.; Oliveira, A. B.; Raslan, D. S.; Starling, S.; Chiari, E.; Bioorg. Med. Chem. Lett. 1997, 7, 2043.

14. Goulart, M. O. F.; de Abreu, F. C.; Ferraz, P. A. L.; dos Santos, A. F.; Santana, A. E. G.; Planta Med. 2001, 67, 92.

15. dos Santos, A. F.; Ferraz, P. A. L.; Pinto, A. V.; Pinto, M. C. R. F.; Goulart, M. O. F.; Santana, A. E. G.; Int. J. Parasitol. 2000, 30, 1199.

16. Lima, N. M. F.; dos Santos, A. F.; Porfírio, Z.; Goulart M. O. F.; Sant'Ana A. E. G.; Acta Trop. 2002, 83, 43.

17. Kumagai, Y.; Tsurutani, Y.; Shinyashiki, M.; Takeda, S. H.; Nakai, Y.; Yoskikawa, T.; Shimojo, N.; Environm. Toxicol. Pharmacol. 1997, 3, 245.

18. De Abreu, F. C.; Ferraz, P. A. L.; Goulart. M. O. F.; J. Braz. Chem. Soc. 2002, 13, 19.

19. Kovacic, P.; Becvar, L. E.; Curr. Pharm. Des. 2000, 6, 143.

20. Ossowski, T.; Pipka, P.; Liwo, A.; Jeziorek, D.; Electrochim. Acta, 2000, 45, 3581.

21. Hooker, S.C.; J. Am. Chem. Soc. 1936, 59, 1190.

22. Leffler M. T., Hathaway R. J.; J. Am. Chem. Soc. 1948, 70, 3222 .
23. Hooker, S.C.; J. Chem. Soc. 1896, 69, 1357.

24. dos Santos A. F.; Ferraz, P. A. L.; De Abreu, F. C.; Chiari E.; Goulart, M. O. F.; Sant'Ana, A. E. G. In Natural Products in the New Millenium. Prospects and Industrial Applications; Rauter, A. P.; Araújo, M. E.; Palma, F. B.; Justino, J.; Santos, S. P. eds., Kluwer Academic Publishers: Dordrecht, 2002, p. 255261.

25. Ferraz, P. A. L.; De Abreu, F. C.; Tonholo, J.; Chiari, E., Pinto, A. V., Glezer, V.; Goulart, M.O.F.; J. Electroanal. Chem. 2001, 507, 275.

26. Marston, A.; Hostettmann, K.; Phytochemistry 1985, 24, 639.

27. Andrews, P.; Thyssen, J.; Lorke, D.; Pharmacol Ther. 1983, 19, 245.

28. Ashnagar, A.; Bruce, J. M.; Dutton, P. L.; Prince, R. C.; Biochim. Biophys. Acta, 1984, 801, 351.

29. Crawford, P.W.; Carlos, E.; Ellegood, J. C.; Cheng, C. C.; Dong, Q.; Liu, D. F.; Luo, Y. L.; Electrochim. Acta 1996, 41, 2399.

30. Turovska, B.; Stradinš, J.; Logins, J.; Strazdinš, I.; Dregeris, J.; J. Electroanal. Chem. 1995, 394, 229.

31. Turovska, B.; Stradinš, J.; Freimanis, J.; Strazdinš, I.; Logins, J.; Dregeris, J.; J. Electroanal. Chem 1996, 414, 221.

Received: June 7, 2002 Published on the web: October 9, 2002 